smoking history or that detailed and reliable information on smoking history is entered into the analysis. Sadly, although detailed smoking histories were taken in at least two of the three studies, smoking was included in their regression analyses only as a binary variable discriminating those who had ever smoked from non-smokers. None of the studies has therefore excluded the possibility that keepers of pet birds may tend to be heavier smokers. The influence of smoking may also have contributed to the differences in the estimates of the odds ratio between the studies: both Holst et al and Kohlmeier et al selected healthy age and sex matched community controls, who are less likely to have been heavy smokers than the cases ${ }^{89}$; Gardiner et al used as controls hospital inpatients, who are generally more likely to be smokers, particularly those admitted because of heart disease. ${ }^{10}$ Such selection bias among the controls may have contributed to the smaller odds ratio in this study.

Gardiner et al's findings may also have been influenced by the tendency for cases to be interviewed by one investigator and controls by others. The authors have attempted to adjust for this systematic bias, but, without measuring the extent of the bias, it is probably not possible to remove it simply by adjusting for the interviewer in the analysis. A further problem is that the studies used exposure to pet birds from five years before diagnosis. For some types of tumour this is likely to include exposure occurring after rather than before the development of the cancer, raising the possibility of reverse causation. " Holst et al argued, however, that this was unlikely to be the case since increased exposure to birds was evident in cases up to 35 years before diagnosis. ${ }^{8}$

Despite the possible sources of error in these studies it is essential to give the work credit. If valid, the association with pet birds would not only identify an easily avoidable cause of disease but also open new avenues for pathogenetic research. The immediate priority is to build on these findings by conducting investigations that control properly for the effects of smoking. One solution would be to study lung cancer only in lifetime non-smokers, perhaps by combining data on nonsmokers from these three studies. The finding in the two papers in this issue of an association with intake of vitamin A also highlights the potential value of investigating dietary intervention in the prevention of lung cancer. ${ }^{6}$ Smoking may remain the most important cause of lung cancer, but we should not ignore other possible causes.

JOHN BRITTON Senior Lecturer SARAH LEWIS Statistician

Respiratory Medicine Unit,

City Hospital,

Nottingham NG5 1PB

1 Johnson K, Callum C, Killoran A. The smoking epidemic. Counting the cost in England. London: Health Education Authority, 1991.

Carstensen $\mathrm{JM}$, Axelson $\mathrm{O}$. Changes in non-smoking related lung cancer with special reference to mortality trends in Swedish women. In: Davis DL, Hoel DG, eds. Trends in cancer mortality in industrial countries. New York: New York Academy of Sciences, 1990:159-64.

3 Axelson $\mathrm{O}$. Davis DL, Forestiere F, Schneidermann $\mathrm{M}$, Wagener $\mathrm{D}$. Lung cancer not autributable to smoking. In: Davis DL, Hoel DG, eds. Trends in cancer mortality in industrial countries. New York: New York Academy of Sciences 1990:165-78.

4 Cres RH, Southwood TRE Risks from ionising radiation. Nature 1989:338:197-8.

5 Spiro SG. Lung tumours. In: Brewis RAL, Gibson GJ, Geddes DM, eds. Respiratory medicine. London: Baillière Tindall, 1990:832-79.

Willett WC. Vitamin A and lung cancer. Nutr Rev 1990;48:201-11.

7 Samet JM, Humble CG, Pathak DR. Personal and family history of respiratory disease and lung cancer risk. Am Rev Respir Dis 1986;134:466-70.

8 Holst PA, Kromhout D, Brand R. Pet birds as an independent risk factor for lung cancer. BMf 1988;297:1319-21.

9 Kohlmeier L, Arminger G, Bartolomeycik S, Bellach B, Rehm J, Thamm M. Pet birds as an independent risk factor for lung cancer: case-control study. B.MF 1992;305:986-9.

10 Gardiner AJS, Forey BA, Lee PN. Avian exposure and bronchogenic carcinoma. BMJ 1992; 305:989-92.

11 Geddes DM. The natural history of lung cancer: a review based on rate of tumour growth. $\mathrm{Br} f \mathrm{Dis}$ Chest 1979;73:1-17.

\title{
Mental health services for children
}

\section{Receiving too little attention}

The Health of the Nation's targets for mental illness are to improve the health and social functioning of mentally ill people and to reduce the suicide rate. ${ }^{1}$ The white paper has little to say on the mental health of children and adolescents, though it acknowledges their vulnerability to disorders which, if untreated, may have serious consequences in adult life. Preventing behavioural disorders in children is listed as a possible future target.

Improving the mental health of children and adolescents should be an end in itself and not merely a means of improving adult functioning, though it would achieve this. For example, childhood bereavement and parental loss and repeated separations from attachment figures (even without death) are associated with increased rates of depression in childhood and later life,$^{2-}$ and therapeutic intervention with children facing or experiencing loss improves their mental health and functioning - at least in the short term..$^{56}$

Many child and adolescent mental health services, however, are so stretched that they cannot extend their services for assessment and treatment to offer preventive interventions. These services rely heavily on social workers with special skills in family therapy and parental counselling; all over the country these workers are being removed from child psychiatric clinics as the social services departments of local authorities feel the financial pinch.

What of youthful suicides? Of every 100000 young people aged between 15 and 19, 400 attempt suicide each year and three succeed. ${ }^{7}$ At least a quarter of these young people have serious psychiatric disorders, ${ }^{8}$ and $10 \%$ of boys and $3 \%$ of girls who attempt suicide go on to kill themselves. ${ }^{9}$ How are hard pressed child and adolescent psychiatrists to meet the demand for reducing suicide rates in young people in addition to other increasing demands on their time, ${ }^{10}$ and dwindling resources? One solution is for health service managers to recognise the improvements in therapeutic services that would result from employing all therapists, rather than relying on departments of social services and education to fund many of them.

Only four qualified child psychotherapists are employed by the NHS north of Birmingham, " and the NHS employs only a handful of the family therapists working in child psychiatric clinics. Yet the effectiveness of both these therapies has been shown in some common conditions ${ }^{7}$ and, although clinical psychologists, child psychiatric nurses, and consultant child and adolescent psychiatrists can provide some of the therapy, lack of specialised training in some cases and their small numbers preclude every troubled child who needs treatment from getting it.

In this context a guide produced for purchasers of mental health services for children and adolescents by the charity Action for Sick Children is welcome. With Health in Mind, which describes the disorders seen in child psychiatric clinics, 
defines their prevalence, and sets the aims and objectives of mental health services for this age group, giving helpful guidelines on dealing with the knotty problems of quality assurance, audit, monitoring contract compliance, and meeting users' needs. ${ }^{7}$ It should be studied not only by purchasers but also by providers of services in the new NHS, including managers of services for mental health and children in trust hospitals.

Despite the high prevalence of mental health problems among children-about 1 in 10 children have disorders of emotions or conduct or other psychiatric disorders that interfere with development and functioning-child and adolescent psychiatry has always been a cinderella specialty. If the government seriously wants to reduce the prevalence of mental illness resulting in suicide it must encourage purchasers to use the guidelines produced by Action for the Sick Child to ensure the provision of appropriate services. By redistributing the derisory amount currently spent on child mental health it will not achieve this aim.

DORA BLACK

Consultant Child and Adolescent Psychiatrist,

Royal Free Hospital,

London NW3 2RG

1 Secretary of State for Health. The health of the nation. London: HMSO, 1991. (Cm 1986.)

2 Brown G, Harris T. The social origins of depression. London: Tavistock, 1978.

3 Goodyer IM. Life experiences, development and childhood psychopathology. Chichester: Wiley, 1990.

4 Parkes CM. Bereavement: studies of grief in adult life. Harmondsworth: Penguin, 1986.

5 Black D, Urbanowicz MA. Family intervention with bereaved children. $f$ Child Psychol Psychiatry 1987;28:467-76.

6 Black D, Urbanowicz MA. Bereaved children-family intervention. In: Stevenson JE, ed. Recent research in developmental psychopathology. Oxford: Pergammon, 1985;179-87.

$7 \mathrm{Kurtz}$ Z. With health in mind. London: Action for Sick Children, 1992.

8 Taylor EA, Stansfeld SA. Children who poison themselves. I. A clinical comparison with psychiatric controls. Brf Psychiatry 1984;145:127-35.

Otto U. Suicidal acts by children and adolescents: a follow-up study. Acta Psychiat Scand 1972;233[suppl]:5-23.

10 Black D. Consultant manpower in child psychiatry. Psychiatric Bulletin 1989;13:32-5.

11 Drabble M. Someone to watch over them. Times 1992 July 8:C5.

\section{"Without work all life goes rotten"}

\section{Unemployment kills, ruins health, and destroys families}

Nothing to do with time; nothing to spend; nothing to do tomorrow nor the day after; nothing to wear; can't get married. A living corpse; a unit of the spectral army of the three million lost men.

\section{WALTER GREENWOOD}

Politicians may not understand what unemployment feels like from the inside, but writers do. Albert Camus said that "Without work all life goes rotten"; Walter Greenwood produced the quote above in his book Love on the Dole; and George Orwell described the miseries of unemployment in The Road to Wigan Pier, ${ }^{2}$ observing that "It is only when you lodge in streets where nobody has a job [and] where gettting a job seems about as probable as owning an aeroplane ... that you begin to understand the changes that are being worked in our society." The week when 30000 British miners learnt that they would lose their jobs and when unemployment reached 2.84 million seems like the right time to remind doctors and politicians of just how much we know about how unemployment damages health. ${ }^{34}$

Many of those miners who will lose their jobs will die prematurely as a result. Unemployment raises the chance that a man will die in the next decade by about a third, and for those in middle age - with the biggest commitments - the chance doubles. ${ }^{56}$ The men are most likely to die from suicide, cancer, and accidents and violence. Their wives will also face a higher chance of dying and so will their children and unborn babies. ${ }^{3}$ Separation, divorce, and family violence are also linked with unemployment. ${ }^{37}$ Exactly how unemployment kills is unclear, but it is through a combination of poverty, stress, adoption of unhealthy behaviours, and the devastating effect on mental health. And it is not only miners who are affected: many people in the south east of England are experiencing unemployment for the first time in cultures that are less familiar with the ravages of joblessness.

The physical health of the unemployed tends to deteriorate, and they are likely to visit their general practitioners more often - particularly with chronic cardiovascular conditions. ${ }^{89}$ But it is mental health that is most harmed by unemployment. The unemployed experience anxiety, depression, neurotic disorders, poor self esteem, and disturbed sleep patterns, and they are more likely than the employed not only to kill themselves but also to injure themselves deliberately. ${ }^{4}$ The psychological damage stems mainly from loss-of status, purpose, social contacts, income, and a sense of belonging and mattering. Unemployment also brings stigma, humiliation, and a reduced scope for making decisions. Marie Jahoda and her colleagues described in their classic studies of Marienthal in the 1930s how the Austrian town was frozen by mass unemployment into apathy, poverty, and pointlessness, ${ }^{10}$ and Adrian Sinfield has observed that "Prolonged unemployment is for most people a profoundly corrosive experience, undermining personality and atrophying work possibilities."

For many of those in the abandoned mining communities it will be impossible to find new jobs, which is tragic as reemployment - in a job of equal value and status - is the only certain "cure" for the misery of unemployment. Research into ways of ameliorating the harmful effects of unemployment is much less developed than research into whether unemployment harms and how, but retraining, counselling, advice on benefits, education, careers advice, and social action may all help. Doctors can help with these activities, but politicians have greater scope for action. So far, however, they have shown little sign of understanding the extent of the misery that is being created. For instance, the precipitous way in which some miners are being thrown out of jobs held for 20 30 years with only two days' warning is likely to be extremely damaging. We must hope that those ministers particularly responsible for health can make their voices heard at a Cabinet table understandably preoccupied with a collapsing economy. After all, isn't that the point of The Health of the Nation? Or will it become The Health of Two Nations?

RICHARD SMITH Editor, $B M \mathcal{F}$

1 Greenwood W. Love on the dole. Harmondsworth: Penguin, 1969. (First published 1933).

2 Orwell G. The road to Wigan pier. London: Victor Gollancz, 1937.

3 Smith R. Unemployment and health: an opportunity and a disaster. Oxford: Oxford University Press, 1987.

4 Warr PB. Work, unemployment, and mental health. Oxford: Clarendon Press, 1987.

5 Moser KA, Fox AJ, Jones DR, Goldblatt PO. Unemployment and mortality: further evidence from the OPCS longitudinal study 1971-81. Lancet 1986;i:365-6.

6 Moser KA, Goldblatt PO, Fox AJ, Jones DR. Unemployment and mortality: comparison of the 1971 and 1981 longitudinal study census samples. $B M \mathcal{F} 1987 ; 294: 86-90$.

7 Popay J. Unemployment and the family. London: Unemployment Alliance, 1984.

8 Beale N, Nethercott S. Job loss and family morbidity: a study of factory closure. $f$ R Coll Gen Pract 1985;280:200-2.

Beale N, Nethercott S. The nature of unemployment morbidity. 2. Description. $f R$ Cell Gen Pract 1988;38:390-4.

10 Jahoda M, Lazarsfield PF, Zeisl H. Marienthal: the sociography of an unemployed community. London: Tavistock, Publications. 1972. (German edition published 1933).

11 Sinfield A. What unemployment means. Oxford: Martin Robertson, 1981. 